\title{
IN-VITRO EVALUATION OF PLANT LEAF AND OIL CAKE EXTRACTS AGAINST RHIZOCTONIA SOLANI CAUSING FRENCHBEAN ROOT ROT DISEASE
}

KUMAR. M, KUDADA. N, SAURABH. A \& ZEESHAN. N

\author{
Department of Plant Pathology Birsa Agricultural University, Ranchi, Jharkhand, India
}

\begin{abstract}
S
In the present study, effects were made to explore the efficacy of various plant leaf and oil cake extracts against Rhizoctonia solani. Efficacy of eight leaf extracts viz., Neem (Azadirachta indica), Karanj (Pognamia pinnata), Bakain (Melia azadirachta), Datura (Datura stramonium), Bael (Aegle marmelos), Eucalyptus (Eucalyptus obliqua), Sindwar (Vitex negunda), Marigold (Tagetes erecta) at 10 and 20 percent concentrations and nine oil cake extracts viz., Niger (Carthanus tinctrorius), Neem (Azadirachta indica), Soybean (Glycine max), Mustard (Brassica compestris), Linseed (Linum usitatissimum), Sesamum (Sesamum indicum), Karanj (Pongamia pinnata), Groundnut (Arachis hypogaea), Mahua (Madhuca indica) at 5 and 10 percent concentrations were evaluated by using poisoined food technique in-vitro condition and recorded the radial growth of the mycelium. The neem (A. indica) leaf extract recorded maximum mycelial growth inhibition by 66.87, 54.12 percent after 4 and 7 days incubation, respectively at 10 percent concentration and 98.17 and 74.58 percent after 4 and 7 days incubation, respectively at 20 percent concentrations. Maximum mycelial growth inhibition by 64.15, 66.48 percent after 4 and 7 days incubation, respectively at 5 percent concentration and by 81.84, and 64.97 percent after 4 and 7 days incubation, respectively at 10 percent concentration was recorded with neem oil cake extracts (A. indica). The present study revealed that neem leaf and oil cake extracts could be explored for the possible control of deadly pathogen $R$. solani.
\end{abstract}

KEYWORDS: In-vitro, Plant leaf/ oil cake extracts, Rhizoctonia Solani \& Frenchbean

Received: Apr 07, 2017; Accepted: Jun 03, 2017; Published: Jun 14, 2017; Paper Id.: IJASRJUN201758

\section{INTRODUCTION}

French bean (Phaseolus vulgaris L.), is one of the most important leguminous crops grown throughout the world. It belongs to the family Fabaceae, which is also known as kidney beans, haricot bean, snap bean and Navy bean. In India, the fresh pod used as vegetables are called, fresh bean and the dried pod for pulse is called Rajmah. The crop French bean is affected by many fungal, bacterial, viral and nematode diseases. Among fungal diseases, root rot caused by $R$ solani is most destructive and occurs at pre- and post-emergence stage of seedlings and causes significant losses in yield. Rhizoctonia rot of carrot, etc. Rhizoctonia solani Kuhn causing root rot disease is a soil inhabitant, polyphagus and a facultative parasite. It is known to cause disease in many crops including rice, barley, urdbean, soyabean, potato etc. (Upmanyu et at., 2002). This pathogen causes a variety of symptoms, like crown rot, sheath blight, web blight, root rot etc. on different hosts. The yield losses from this disease have been reported 8.5 to $64.7 \%$ from Bangalore (Sharma and Sohi, 1980), though the fungus is seed borne and soil borne. Soil-borne inoculum is more important in causing infection and disease development. Plant extracts are eco-friendly, possess structural diversity, complexity and are frequently impregnated with halogenated atoms (Duke et al., 2000). Presently, more than 200 species of plant pathogens are reported to be resistant to chemical pesticides (Varma and Dubey, 1999). Tandel et al. (2010) evaluated Phyto extracts of eleven plant 
species against $M$. phaseolina of green gram and revealed that the onion bulb extract produced maximum inhibition (98.14\%) followed by extractions of acacia, ginger, neem, garlic and karanj. A serious setback off these chemicals is environmental pollution that resulted in standby mode. Thus, there is an urgent need for the development of alternative disease control tactics that are effective coupled with eco-friendly nature. These Phyto extracts are cost effective, relatively safe for farmers who can't rely on synthetic pesticides. The present study was ascertained to investigate the anti-fungal activities of leaf extracts of various plant species and oil cake extracts, which are readily available, affordable and environmentally safe and mycelial growth of $R$. solani in-vitro condition.

\section{MATERIALS AND METHODS}

An experiment was carried out in the department of Plant Pathology, Faculty of Agriculture, Birsa Agricultural University, Ranchi, Jharkhand during Rabi 2014-15 and 2015-16 cropping season in in-vitro condition.

\section{In-Vitro Evaluation of Plant Leaf Extracts Against R. Solani}

Eight commonly available plant leaf extracts were used viz., neem (Azadirachta indica), Karanj (Pongamia pinnata), Bakain (Melia Azadirachta), Datura (Datura stramonium), Bael (Aegle nameless), Eucalyptus (Eucalyptus globulus) and Marigold (Tagetes erecta) at 10 and 20 percent concentrations by using poison food technique.

\section{Preparation of Aqueous Extracts}

Fresh plant leaves were collected and washed first with tap water and then with distilled water. A hundred grams of fresh sample were chopped and then crushed in a surface sterilized pestle and mortar by adding $100 \mathrm{ml}$ sterile water (1:1 w/v). The extract was filtered through two layers of muslin cloth. Finally, filtrate thus obtained was used as a stock solution. This formed the standard plant extract solution (100\%). The extracts of different plant leaves were incorporated and sterilized for 20 minutes. Ten and twenty $\mathrm{ml}$ of stock was mixed with 90 and $80 \mathrm{ml}$ of sterilized molten PDA medium, respectively, so, as to get 10 and 20 percent concentration. The medium thoroughly shaken for uniform mixing of extracts and then after adding the botanical again the media was sterilized. Twenty ml of medium was poured into each of the $90 \mathrm{~mm}$ sterile Petri plates. Each plate was inoculated with $5 \mathrm{~mm}$ mycelial discs taken from the periphery of fungal culture and incubated at $25 \pm 1^{\circ} \mathrm{C}$. The experiment was arranged in a completely randomized design (CRD). Three replications were maintained for each treatment. The fungus grown on PDA without plant extracts served as control. Mean colony diameter in each case was recorded by taking the diameter, the colony in two directions. Radial growth of the fungus was measured after four and seven days of inoculation. The efficacy of plant extracts was expressed as percent of radial growth over the control, which was calculated by using the following formula (Vincent, 1947). The data were analyzed statistically:

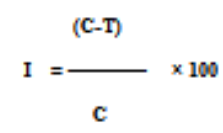

Where,

$\mathrm{I}=$ percent inhibition

$\mathrm{C}=$ radial growth in control 
$\mathrm{T}=$ radial growth in treatment

\section{In-Vitro Evaluation of Different oil Cake Extracts against R. Solani}

Nine oil cakes extract viz., Niger (Carthamus tinctrorius), Neem (Azadirachta indica), Soybean (Glycine max), Mustard (Brassica compestris), Linseed (Linum usitatissimum), Sesamum (Sesamum indicum), Karanj (Pongamia pinnata), Groundnut (Arachis hypogaea), Mahua (Madhuca indica) was collected and tested for their efficacy against $R$. solani by poisoned food technique. The oil cakes were first soaked in sterile distilled water at the rate of one gm. in one $\mathrm{ml}$ of water and kept overnight and the ground in pestle and mortar, by adding sterile water at the ratio of 1:1 (w/v). The macerate was squeezed using cotton to get the extract. The macerate was strained through two layers of muslin cloth and finally through Whatman No. 1 filter paper and this formed the standard plant extract solution (100\%). This was further diluted with sterilized distilled water (v/v) to have the required concentrations (10 and 20\%). The PDA medium was mixed with different concentrations viz., 10 and $20 \%$ of oil cakes. Mycelium plug of the pathogen was placed at the centre of each petri plate and incubated at $25 \pm 1^{\circ} \mathrm{C}$. The growth of the diameter was recorded and percent inhibition was calculated.

\section{RESULTS AND DISCUSSIONS}

Anti-fungal activity of eight plant leaf extracts with different concentrations was assayed by using poisoned food technique. The colony diameter of the fungus was recorded after 4 and 7 days incubation at $25 \pm 2^{\circ} \mathrm{C}$ and percent growth inhibition was calculated.

The results are presented in Table 1, Plate 1 A, B and Figure 1 revealed that all the plant leaf extracts at both concentrations (10 and 20\%) inhibited the mycelial growth significantly over the control. At 10\% concentration, after 4 days incubation Neem leaf extracts (A. Indicia) $\left(\mathrm{T}_{1}\right)$ showed the lowest colony diameter of $20.33 \mathrm{~mm}$ and maximum mycelial growth inhibition of $66.87 \%$, which was significantly superior over all other treatments. After 7 days of incubation, lowest colony diameter of $41.26 \mathrm{~mm}$ and maximum mycelial growth inhibition (54.14\%) was observed by Neem leaf extract $\left(\mathrm{T}_{1}\right)$ followed by Bakain leaf extract $\left(\mathrm{T}_{3}\right)(24.62 \%)$, Karanj leaf extract $\left(\mathrm{T}_{2}\right)(18.69 \%)$ and Datura leaf extract $\left(\mathrm{T}_{4}\right)(11.44 \%)$. These treatments were significantly at par after 7 days incubation. The rest of the treatments in order of superiority were Baal, Eucalyptus and Sindwar, which were statistically at par with each other. Least inhibition of mycelial growth was recorded in Marigold leaf extracts $\left(\mathrm{T}_{8}\right)$ up to 16.56 and 4.89 percent after 4 and 7 days incubation, respectively

At $20 \%$ concentration after 4 days incubation, the minimum colony diameter $(0.97 \mathrm{~mm})$ and maximum mycelial growth inhibition $98.26 \%$ was recorded in Neem leaf extract $\left(\mathrm{T}_{1}\right)$, followed by Bakain leaf extract $\left(\mathrm{T}_{3}\right)(80.31 \%)$, Karanj leaf extract $\left(\mathrm{T}_{2}\right)(66.26 \%)$, Bael leaf extract $\left(\mathrm{T}_{5}\right)(64.86 \%)$ and Datura leaf extract $\left(\mathrm{T}_{4}\right)(60.01)$. Treatment $\mathrm{T}_{1}$ was significantly superior to all other treatments. Thus, treatment $\left(\mathrm{T}_{1}\right)$ Neem leaf extract was statistically at par with the treatment $\mathrm{T}_{3}$ (Bakain leaf extract). The maximum colony diameter was recorded in the control (53.33 mm). After seven days incubation, minimum colony diameter $(20.83 \mathrm{~mm})$ and maximum growth inhibition $(74.58 \%)$ was observed in Neem leaf extract $\left(\mathrm{T}_{1}\right)$ followed by Bakain leaf extract $\left(\mathrm{T}_{3}\right)(67.22 \%)$, Bael leaf extract $\left(\mathrm{T}_{5}\right)(55.92 \%)$, Datura leaf extract $\left(\mathrm{T}_{4}\right)$ $(53.67 \%)$ and Karanj leaf extract $\left(\mathrm{T}_{2}\right)(54.97 \%)$. The minimum inhibition of mycelial growth was recorded by Marigold leaf extracts $\left(\mathrm{T}_{8}\right)$ up to 44.40 and 24.81 percent after 4 and 7 days incubation, respectively at $20 \%$ concentration (Table 2 , Plate 2, Figure 2). The sclerotial production was nil in all the leaf extracts as well as in control after 4 and 7 days incubation. 
These results are in conformity with Singh et al. (1980), who studied the fungitoxic properties of plant extract against Rhizoctonia solani and reported that Azadirachta indica suppress the formation of sclerotia of Rhizoctonia solani and inhibit the growth of mycelium by 53.6 percent, under laboratory condition. Neem leaf extract contains azadirachtin which show a toxic effect against $R$. The salon was also demonstrated by Shivapuri et al. (1997), Sidhan et al. (1999) and Sharma et al. (2005). Kane et al. (2002) reported that crude extract of A. sativum, Eucalyptus and Z. Officinal were effective in inhibiting the mycelial growth of $R$. solani to the extent of cent percent, Mishra et al. (2005) evaluated seven aqueous plant extracts (Calotropis gigantean, Vinca rosea, Ocimum sanctum, A. Indicia, Eucalyptus citriodora, A. cepa and Z. Officinal) against $R$. solani in green gram in-vitro and found that highest inhibitory action (86.11\%) was recorded by Z. Officinal. Tiwari and Das (2011), who reported that plant extracts of P. corylifolia, A. racemosus and C. forskohlii were highly efficacious of the mycelial growth as well as in checking the disease severity of Rhizoctonia solani against sheath blight of rice. Hussain et al. (2014), Wadikar and Nimbalkar (2015) and Naik et al. (2016) evaluated the efficacy of four plants extracts viz., Neem, Pongamia, Subabul gliricidia and observed the radial growth of the mycelium. Neem leaf extract found maximum inhibition $(90 \mathrm{~mm})$ of the fungus at 5, 10 and 15 percent concentration followed by Pongamia leaf extract at seven days after incubation. Among the leaf extract, neem and Pongamia leaf extracts were found to be effective against root rot pathogens, $R$. solani.

The extracts of nine oil cakes at different concentrations were evaluated for inhibitory effect on $R$. solani. The results presented in Table 3 indicated that at 5\% concentration, 4 days after incubation. Neem oil cake extract $\left(\mathrm{T}_{2}\right)$ showed a lowest colony diameter of $27.00 \mathrm{~mm}$ and maximum mycelial growth inhibition of 64.15 percent which was significantly superior over all other treatments. This treatment was followed by Mustard oil cake extract $\left(\mathrm{T}_{4}\right)(55.82 \%)$, Karanj oil cake extract $\left(\mathrm{T}_{7}\right)(49.12 \%)$ and Niger oil cake extract $\left(\mathrm{T}_{1}\right)(37.40 \%)$. Minimum mycelial growth $(21.66 \%)$ was recorded in Linseed oil cake extracts $\left(\mathrm{T}_{5}\right)$ followed by. Soybean oil cake extract $\left(\mathrm{T}_{3}\right)(24.63 \%)$, Sesamum oil cake extract $\left(\mathrm{T}_{6}\right)$ (26.54\%), Groundnut oil cake extract $\left(\mathrm{T}_{8}\right)(27.86 \%)$ and Mahua oil cake extract $\left(\mathrm{T}_{9}\right)(28.76 \%)$. However, the control plate recorded colony diameter of $75.33 \mathrm{~mm}$ after 4 days incubation. The sclerotial production was nil in all the treatments as well as in control.

After 7 days incubation, at $5 \%$ concentration, Neem oil cake extract $\left(\mathrm{T}_{2}\right)$ absorbed lowest colony diameter of $30.16 \mathrm{~mm}$ and maximum mycelial growth inhibition of 66.48 percent. This treatment $\left(\mathrm{T}_{2}\right)$ was followed by Mustard oil cake extract $(32.58 \%)$ and Karanj oil cake extract $\left(\mathrm{T}_{7}\right)(30.36 \%)$. The linseed oil cake extract showed no inhibition of mycelial growth at $10 \%$ concentration. The control plate recorded colony diameter of $90.00 \mathrm{~mm}$. The sclerotial production was found in the treatment ( $\mathrm{T}_{9}$ ) (Table 3, Plate 3 A, B Figure 3). After 4 days incubation at $10 \%$ concentration, Neem oil cake extract (Azadirachta indica) $\left(\mathrm{T}_{2}\right)$ showed a lowest colony diameter of $10.50 \mathrm{~mm}$ and maximum mycelial growth inhibition of 81.84 percent. This treatment was followed by Mustard oil cake extract $\left(\mathrm{T}_{4}\right)(78.97 \%)$, Karanj oil cake extract $\left(\mathrm{T}_{7}\right)(72.47 \%)$, Mahua oil cake extract $\left(\mathrm{T}_{9}\right)(59.31 \%)$, Groundnut oil cake extract $(\mathrm{T} 8)(51.62 \%)$ and Sesamum oil cake extract (T6) (51.11\%). The minimum growth inhibition (28.17\%) was recorded in the Linseed oil cake extract at 10 percent concentration. However, the control plate showed a maximum colony diameter of $57.83 \mathrm{~mm}$.

After 7 days incubation, at 10 percent concentration, Neem oil cake extract $\left(\mathrm{T}_{2}\right)$ showed lowest colony diameter of $30.00 \mathrm{~mm}$ and maximum mycelial growth inhibition of 64.97 percent, which was followed by Mustard oil cake extract $\left(\mathrm{T}_{4}\right)$ $(62.30 \%)$, Karanj oil cake extract $\left(\mathrm{T}_{7}\right)(61.30 \%)$ and Mahua oil cake extract $\left(\mathrm{T}_{9}\right)(43.89 \%)$. The minimum of mycelial growth was observed in the Linseed oil cake extract $\left(\mathrm{T}_{5}\right)(26.07 \%)$. The radial growth of the control plate showed a 
maximum colony diameter of $85.66 \mathrm{~mm}\left(\mathrm{~T}_{10}\right)$ (Table 4, Plate $4 \mathrm{~A}$, B and Figure 4).

The findings in the present studies are in corroboration with those described earlier by other workers viz., Jha et al (2000), who reported that among oil cakes tested, B. juncea cake exhibited maximum inhibition of mycelial growth (51.8\%) at 5\% concentration against Macrophomina phaseolina causing root rot of okra. Sonali and Gupta (2004) reported that aqueous extract of mustard cake (5\%), neem cake (1\%), pine needles $(5 \%)$, deodar needles $(3 \%)$ and neem oil $(3 \%)$, respectively leading to reduce in-vitro germination of sclerotia of test pathogen $S$. rolfsii Sacce, causing seedling blight disease in apple nurseries, as compared to control. Combination of mustard cake (5\%) with neem oil (3\%), neem cake (1\%) with deodar needles (3\%) and neem oil (3\%) and mustard cake (5\%) resulted total inhibition of sclerotia germination. Pan et al. (2009) reported that efficacy of mustard cake-wheat bran formulation of T. harzianum of test best product formulates against root rot disease of cabbage and collar rot of groundnut.

\section{CONCLUSIONS}

The difference between the effectiveness of plant extracts and oil cakes at different concentrations may be due to the presence of certain chemical substances in these leaf extracts and oil cakes. The chemical substances, which have an inhibitory effect, may be less at low concentration, but other substances, which were essential for fungal growth, may be present in sufficient amount. But, at higher concentration due to the enhancement of inhibitory chemical substances, growth supporting substances may be reduced. It is concluded that the neem leaf and oil cake extracts were found to be more effective in all the concentrations in inhibiting the mycelial growth of the test fungus ( $R$. solani) up to 7 days, which was superior over control, and the rest of the leaf and oil cake extracts used during the course of investigation. Hence, these cost effective, eco-friendly natural products can be used as an alternative to hazardous fungicides.

\section{REFERENCES}

1. Duke, S. O., Romagni, J. G. and Dayan, F. E. (2000). Natural products as sources for new mechanism of herbicidal action. Crop Protec. 19:583-589.

2. Hussain Azbar, Muhammad Saeed Awan, Sher Wali Khan, Muhammad Anees, Sartaj Ali Qammar Abbas, Amjad Ali (2014). Bioefficacy of botanical extracts and bioagents against sclerotial isolates of Rhizoctonia solani. Journal of Biodiversity and Environmental Sciences. 4(6): 370-380

3. Jha, A. K., Dubey, S. C. and Jha, D. K. (2000). Evaluation of different leaf extracts and oil cakes against Macrophomina phaseolina causing collar rot of okra. J. Research, 12 (2): 225-228.

4. Kane, P.V., Kshirsagar, C.R ., Jadhav, A.C. and Pawar, N. B. (2002). In-vitro evaluation of some plant extracts against Rhizoctonia bataticola in chickpea. J, Maharastra Agric. Univ., 27 (1): 101-12.

5. Mishra, B.D., Sahoo. K.C., Sugata, G., Rout, M.K. (2005). In-vitro evaluation of plant extracts, oil cakes and agro-chemicals against web blight of green gram caused by Rhizoctonia solani, J. Mycopatho. Res., 43: 225-257.

6. Naik, T.S., Somasekhara, Y. M., Raja, Y. S. and Zaheer Ahamed (2016). In-vitro evaluation of fungal antagonists and plant extracts against French bean root rot caused by Rhizoctonia solani Kuhn. Plant Archives. 16 (1): 159 163.

7. Pan, S., Bose, S. and Jash, S. (2009). Management of root rot of cabbage (R. solani) and groundnut collar rot (Sclerotium rolfsii) with formulation of T. harzianum. J. Mycol. Plant Patho. 39 (2):203-207. 
8. Reddy, C.S., Sudhakar, R., Manoharachary, C., Purohit, D. K., Ram Reddy, S., Singaracharya, M. A. and Girishan, S. (2002). Efficacy of plant products and chemicals in the management of sheath blight of Rice. Frontiers Microbial. Biotech. Pl. Pathol. 76:263-267.

9. Sharma, R.R., Goar, N. H. and Sharma, P. (2005). Effects of plant extract on growth of Rhizoctonia solani and development of maize. Indian J. Mycol. Pl. Pathol. 35 (2): 377- 379.

10. Sharma, S. R. and Sohi, H. S. (1980). Assessment of losses in French bean caused by Rhizoctonia solani Kuhn. Indian Phytopath. 33: 366-369.Shivapuri, A., Sharma, O. P. and Jhamaria, S. L. (1997). Fungistatic properties of plant extract against pathogenic fungi. J.Mycol. Pl. Pathol. 27: 29-31.

11. Sidhan, G.S., Hooda, I. and Parashar, R.D. (1999). Effect of some plant extracts on the vegetable growth of root rot causing fungi. Indian J. Mycol. Pl. Pathol. 29(1):110-111.

12. Singh, U.P. M., Singh, H. B. and Singh, R. B. (1980). Effect of plant extract on growth of Rhizoctonia spp. Mycologia, 72:1077-1093.

13. Sonali and Gupta, A. K. (2004). Efficacy of plant materials on inhibition of Sclerotial germination of Sclerotium rolfsii. J. Mycol. Pl. Pathol., 34 (2): 82-84.

14. Tandel, D. H., Sabalpara, A. N. and Pandya, J. R. (2010). Efficacy of phyto-extracts on Macrophonima phaseolina (Tassi) Goid causing leaf blight of green gram. Int. J Parma. Biosci. 2:1-5.

15. Tiwari, R. K. S and Das, Kuntal (2011). Inhibitory effect of cow urine based plant extracts against Rhizoctonia solani causing sheath blight of rice. Indian Phytopath. 64(3):265- 268.

16. Upmanyu, S., Gupta, S. K. and Shyam, K. R. (2002). Innovation approaches for the management of root rot and web blight (Rhizoctonia solani) of French bean. J. Mycol. Pl. Pathol. 32(3): 317-331.

17. Varma, J. and Dubey, N. K. (1999). Prospective of botanical and microbial products as pesticides of tomorrow. Curr. Sci. 76(2):172-179.

18. Vincent, J. M. (1947). Distortion of fungal hyphae in presence of certain inhibitors. Nature, 159:850.

19. Wadikar, M. S. and Nimbalkar, R. K. (2015). Inhibitory Effect of Plant Extracts on Root Rot fungi of Soybean (Glycine max). International Journal of Multidisciplinary Research. I (6): 1-5.

\section{APPENDICES}

Table 1: In-Vitro Evaluation of Different Plant Leaf Extracts on the Mycelial Growth Inhibition of $R$. Solani at $10 \%$ Concentration after 4 and 7 Days Incubation

\begin{tabular}{|l|c|c|c|c|c|c|}
\hline \multicolumn{1}{|c|}{ Treatments } & \multirow{2}{*}{$\begin{array}{c}\text { Concentration } \\
(\boldsymbol{\%})\end{array}$} & $\begin{array}{c}\text { Colony } \\
\text { Diameter } \\
(\mathbf{m m})\end{array}$ & $\begin{array}{c}\text { Growth } \\
\text { Inhibition } \\
(\boldsymbol{\%})\end{array}$ & $\begin{array}{c}\text { Colony } \\
\text { Diameter } \\
(\mathbf{m m})\end{array}$ & $\begin{array}{c}\text { Growth } \\
\text { Inhibition } \\
(\boldsymbol{\%})\end{array}$ & $\begin{array}{c}\text { Sclerotial } \\
\text { Production }\end{array}$ \\
\hline $\begin{array}{l}\text { T1- Neem leaf } \\
\text { extract(Azadirachta indica) }\end{array}$ & 10 & 20.33 & 66.87 & 41.26 & 54.15 & NIL \\
\hline $\begin{array}{l}\text { T2- Karanj leaf } \\
\text { extract(Pongamia pinnata) }\end{array}$ & 10 & 40.66 & 33.73 & 73.16 & 18.69 & NIL \\
\hline $\begin{array}{l}\text { T3- Bakain leaf extract } \\
\text { (Melia azadirachta) }\end{array}$ & 10 & 30.83 & 49.73 & 67.66 & 24.62 & NIL \\
\hline
\end{tabular}




\begin{tabular}{|l|c|c|c|c|c|c|}
\hline \multicolumn{7}{|c|}{ Table 1: Contd., } \\
\hline $\begin{array}{l}\text { T4- Datura leaf } \\
\text { extract(Datura stramonium) }\end{array}$ & 10 & 44.33 & 27.71 & 52.96 & 11.44 & NIL \\
\hline $\begin{array}{l}\text { T5- Bael leaf extract (Aegle } \\
\text { marmelos) }\end{array}$ & 10 & 36.50 & 40.49 & 82.73 & 8.07 & NIL \\
\hline $\begin{array}{l}\text { T6- Eucalyptus leaf extract ( } \\
\text { Eucalyptus obliqua) }\end{array}$ & 10 & 47.33 & 22.83 & 82.36 & 8.48 & NIL \\
\hline $\begin{array}{l}\text { T7- Sindwar leaf extract(Vitex } \\
\text { negunda) }\end{array}$ & 10 & 48.83 & 20.38 & 84.50 & 6.11 & NIL \\
\hline $\begin{array}{l}\text { T8- Marigold leaf } \\
\text { extract(Tagetes erecta) }\end{array}$ & 10 & 51.16 & 16.56 & 85.60 & 4.89 & NIL \\
\hline T9- Control- & - & 61.33 & - & 90.00 & & Yes \\
\hline SEm \pm & & 1.021 & & 3.111 & & \\
\hline CD 5\% & & 3.058 & & 9.316 & & \\
\hline CV \% & 4.175 & & 7.124 & & \\
\hline
\end{tabular}

*Average of three replications

Table 2: In-vitro Evaluation of Different Plant Leaf Extracts on the Inhibition of Mycelia Growth of $\boldsymbol{R}$. Solani at 20\% Concentration after 4 and 7 Days Incubation

\begin{tabular}{|c|c|c|c|c|c|c|}
\hline \multirow[b]{2}{*}{ Treatments } & \multirow[b]{2}{*}{$\begin{array}{c}\text { Concentration } \\
(\%)\end{array}$} & \multicolumn{2}{|c|}{ After 4 days } & \multicolumn{2}{|c|}{ After7 days } & \multirow[b]{2}{*}{$\begin{array}{l}\text { Sclerotial } \\
\text { Production }\end{array}$} \\
\hline & & $\begin{array}{l}\text { Colony } \\
\text { Diameter } \\
(\mathbf{m m})\end{array}$ & $\begin{array}{c}\text { Growth } \\
\text { Inhibition } \\
(\%)\end{array}$ & $\begin{array}{l}\text { Colony } \\
\text { Diameter } \\
(\mathbf{m m})\end{array}$ & $\begin{array}{c}\text { Growth } \\
\text { Inhibition } \\
(\%)\end{array}$ & \\
\hline $\begin{array}{l}\text { T1- Neem leaf extract } \\
\text { (Azadirachta indica) }\end{array}$ & 20 & 0.97 & 98.17 & 20.83 & 74.58 & NIL \\
\hline $\begin{array}{l}\text { T2- Karanj leaf extract } \\
\text { (Pongamia pinnata) }\end{array}$ & 20 & 18.00 & 66.26 & 36.63 & 54.97 & NIL \\
\hline $\begin{array}{l}\text { T3- Bakain leaf extract } \\
\text { (Melia azadirachta) }\end{array}$ & 20 & 10.50 & 80.31 & 26.63 & 67.22 & NIL \\
\hline $\begin{array}{l}\text { T4- Datura leaf extract } \\
\text { (Datura stramonium) }\end{array}$ & 20 & 21.33 & 60.01 & 37.66 & 53.71 & NIL \\
\hline $\begin{array}{l}\text { T5- Bael leaf extract } \\
\text { (Aegle mormelos) }\end{array}$ & 20 & 18.73 & 64.86 & 35.83 & 55.92 & NIL \\
\hline $\begin{array}{l}\text { T6- Eucalyptus leaf } \\
\text { extract ( Eucalyptus } \\
\text { obliqua) }\end{array}$ & 20 & 22.16 & 58.45 & 43.43 & 46.61 & NIL \\
\hline $\begin{array}{l}\text { T7- Sindwar leaf extracts } \\
(\text { Vitex negunda) }\end{array}$ & 20 & 25.26 & 52.60 & 49.66 & 38.92 & NIL \\
\hline $\begin{array}{l}\text { T8- Marigold leaf extracts } \\
\text { (Tagetes erecta) }\end{array}$ & 20 & 29.66 & 44.40 & 61.16 & 24.81 & NIL \\
\hline T9- Control & - & 53.33 & - & 81.36 & - & - \\
\hline $\mathrm{SEm} \pm$ & & 0.663 & & 0.757 & & \\
\hline CD 5\% & & 1.985 & & 2.266 & & \\
\hline $\mathrm{CV} \%$ & & 5.128 & & 3.000 & & \\
\hline
\end{tabular}

*Average of three replications 
In-Vitro Evaluation of Different Plant leaf Extracts on the Inhibition of Mycelial Growth of R. Solani at $10 \%$ Concentration after 4 Days Incubation

Plate 1 A

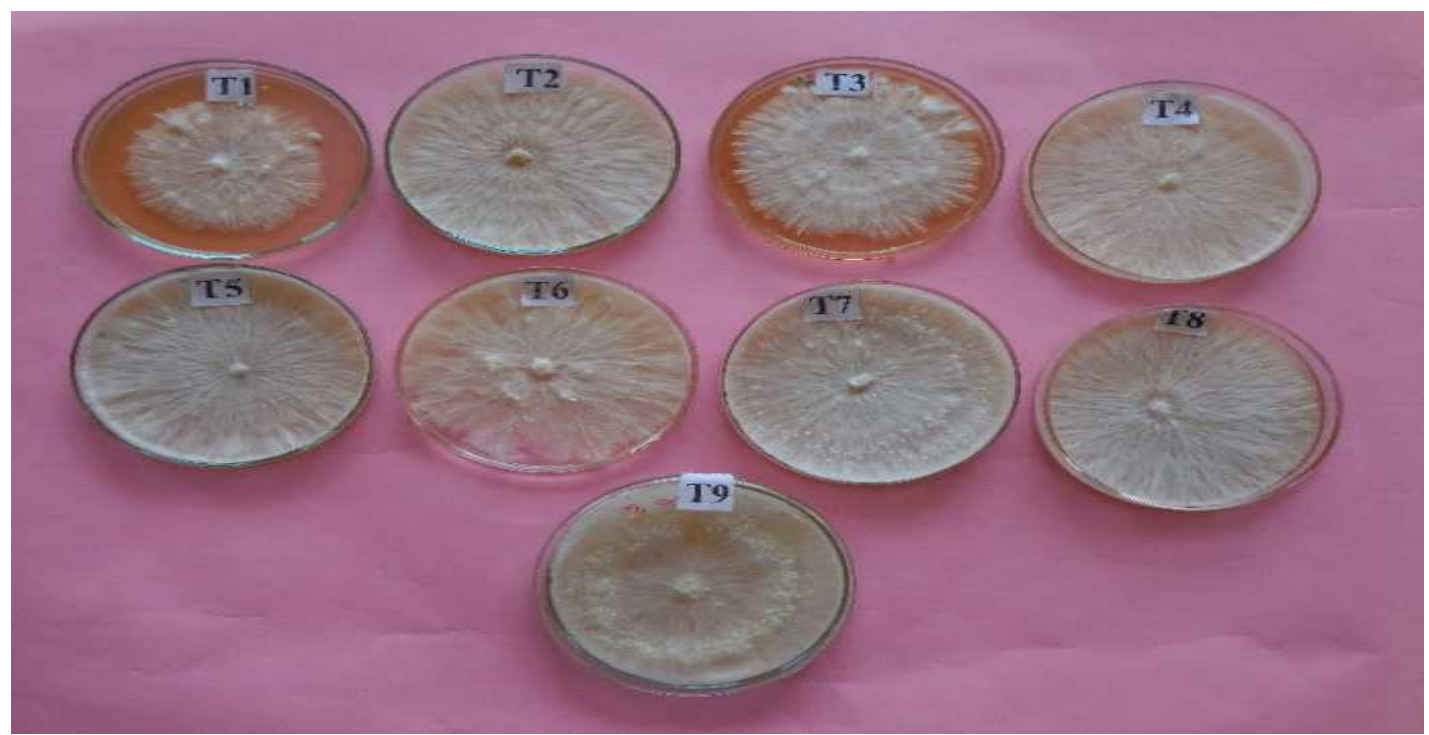

T1- Neem, T2- Karanj, T3- Bakain, T4- Datura, T5- Bael, T6- Eucalyptus, T7- Sindwar, T8- Marigold, T9Control

In-Vitro Evaluation of Different Plant leaf Extracts on the Inhibition ofMycelial Growth of R. Solani at $10 \%$ Concentration after 7 Days Incubation

Plate 1 B

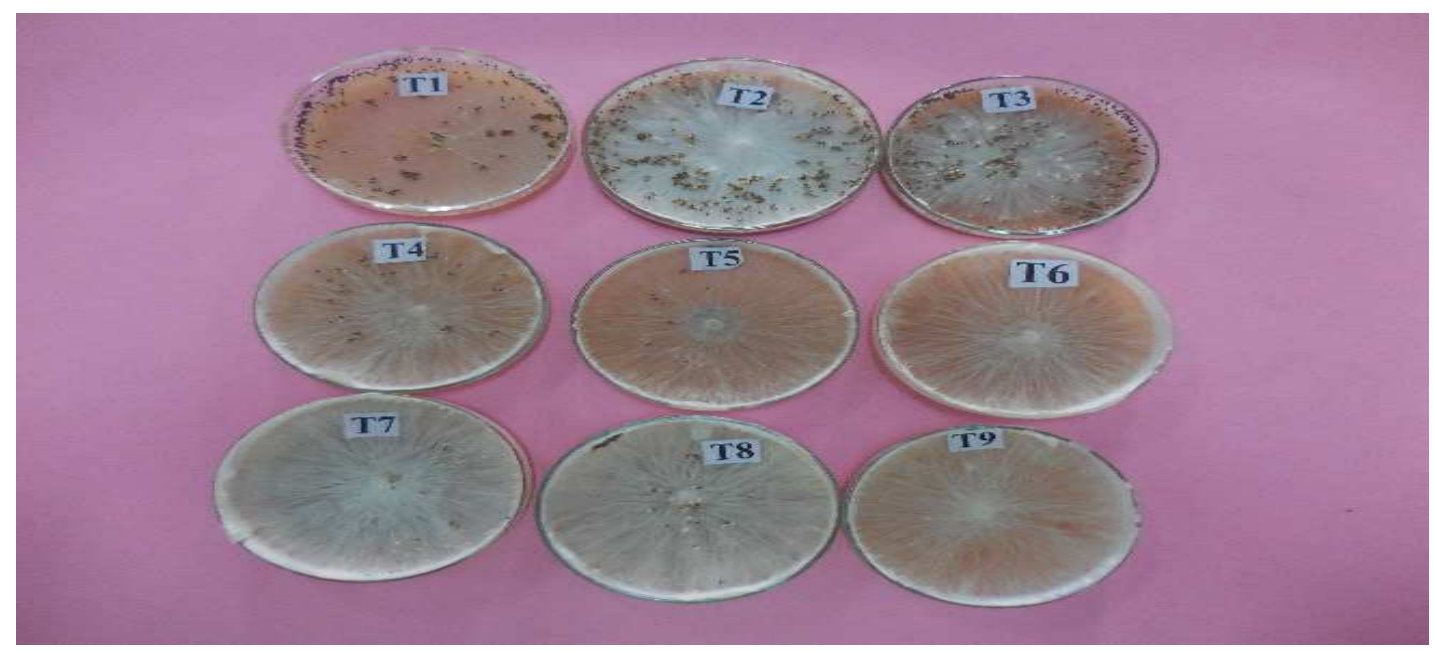

T1- Neem, T2- Karanj, T3- Bakain, T4- Datura, T5- Bael, T6- Eucalyptus, T7- Sindwar, T8- Marigold, T9Control

Figure 1: In-Vitro Evaluation of Different Plant Leaf Extracts on the Inhibition of Mycelial Growth of $\boldsymbol{R}$. Solani at $10 \%$ Concentration after 4 and 7 Days Incubation 
In-vitro evaluation of different plant leaf extracts on the inhibition of mycelial growth of $R$. solani at $20 \%$ concentration after 4 days incubation

Plate 2

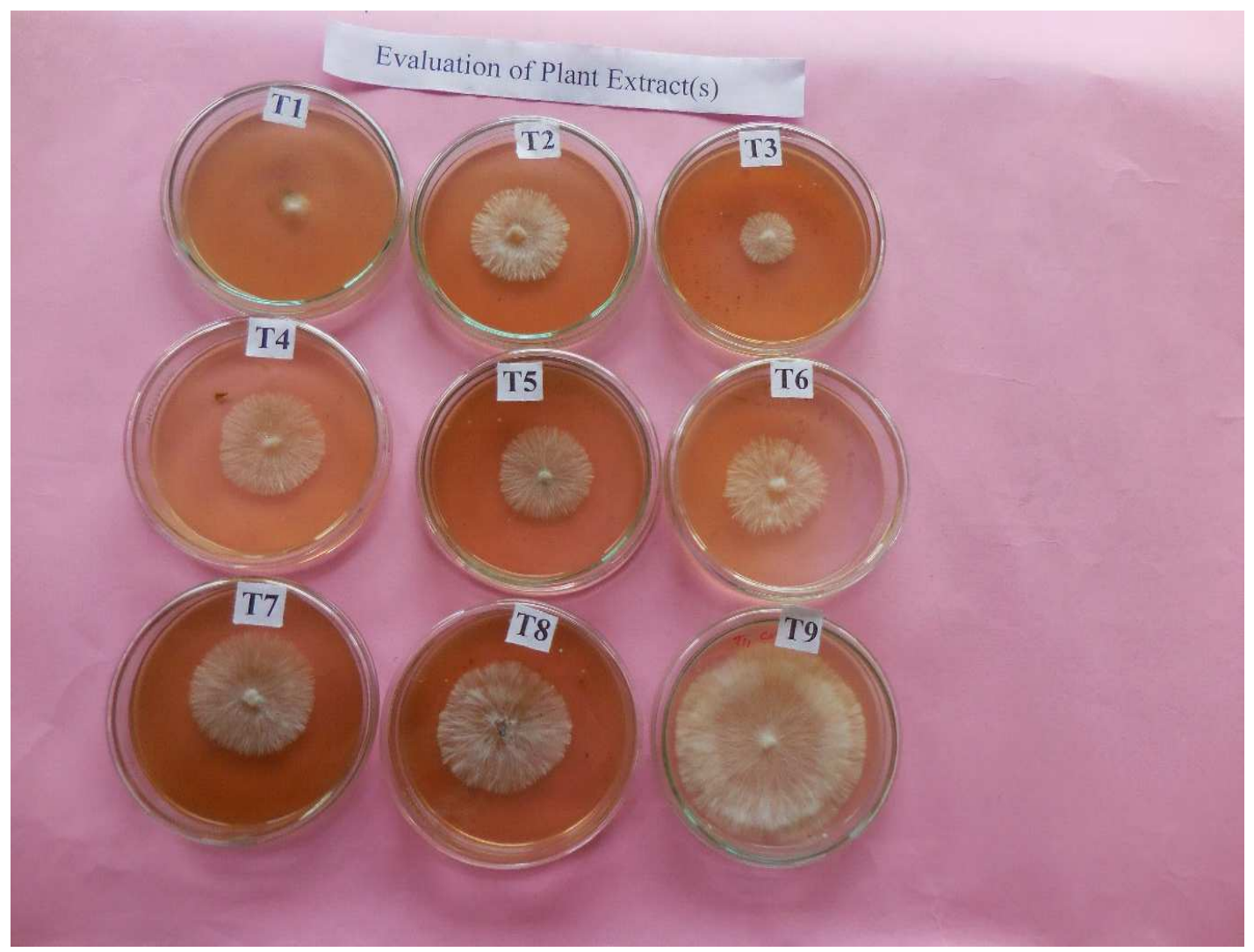

T1- Neem leaf extract, T2- Karanj leaf extract, T3- Bakain leaf extract, T4- Datura leaf extract, T5- Bael leaf extract, T6- Eucalyptus leaf extract, T7- Sindwar leaf extract, T8- Marigold leaf extract, T9- Control

Figure 2: In-Vitro Evaluation of Different Plant Leaf Extracts on the Inhibition of Mycelial Growth of R. Solani at $20 \%$ Concentration after 4 Days Incubation

Table 3: In-Vitro Evaluation of Different Oil Cake Extracts on the Inhibition of Mycelial Growth of $R$. Solani at $5 \%$ Concentration after 4 and 7 Days Incubation

\begin{tabular}{|c|c|c|c|c|c|c|}
\hline \multirow[b]{2}{*}{ Treatments } & \multirow[b]{2}{*}{$\begin{array}{c}\text { Concentration } \\
(\%)\end{array}$} & \multicolumn{2}{|c|}{ After 4 days } & \multicolumn{2}{|c|}{ After7 days } & \multirow[b]{2}{*}{$\begin{array}{l}\text { Sclerotial } \\
\text { Production }\end{array}$} \\
\hline & & $\begin{array}{c}\text { Colony* } \\
\text { Diameter } \\
(\mathrm{mm})\end{array}$ & $\begin{array}{c}\text { Growth } \\
\text { Inhibition } \\
(\%)\end{array}$ & $\begin{array}{l}\text { Colony } \\
\text { Diameter } \\
(\mathrm{mm}) \\
\end{array}$ & $\begin{array}{c}\text { Growth } \\
\text { Inhibition } \\
(\%)\end{array}$ & \\
\hline $\begin{array}{l}\text { T1-Niger cake extract } \\
\text { (Carthanus tinctrorius) }\end{array}$ & 5 & 47.16 & 37.40 & 81.50 & 09.25 & NIL \\
\hline $\begin{array}{l}\text { T2-Neem cake extract } \\
\text { (Azadirachta indica) }\end{array}$ & 5 & 27.00 & 64.15 & 30.16 & 66.48 & NIL \\
\hline $\begin{array}{l}\text { T3-Soyabean cake extract } \\
\text { (Glycine } \max \text { ) }\end{array}$ & 5 & 56.00 & 24.63 & 86.66 & 05.55 & NIL \\
\hline $\begin{array}{l}\text { T4-Mustard cake extract } \\
\text { (Brassica compestris) }\end{array}$ & 5 & 32.06 & 55.82 & 60.66 & 32.58 & NIL \\
\hline $\begin{array}{l}\text { T5-Linseed cake extract (Linum } \\
\text { usitatissimum) }\end{array}$ & 5 & 59.00 & 21.66 & 90.00 & 0.00 & NIL \\
\hline $\begin{array}{l}\text { T6-Sesamum cake extract } \\
\text { (Sesamum indicum) }\end{array}$ & 5 & 55.33 & 26.54 & 89.00 & 01.11 & NIL \\
\hline
\end{tabular}




\begin{tabular}{|l|c|c|c|c|c|c|}
\hline \multicolumn{7}{|c|}{ Table 3: Contd., } \\
\hline $\begin{array}{l}\text { T7-Karanj cake extract } \\
\text { (Pongamia pinnata) }\end{array}$ & 5 & 30.50 & 49.12 & 62.66 & 30.36 & NIL \\
\hline $\begin{array}{l}\text { T8-Groundnut cake extract } \\
\text { (Arachis hypogaea) }\end{array}$ & 5 & 54.33 & 27.86 & 86.33 & 04.07 & NIL \\
\hline $\begin{array}{l}\text { T9-Mahua cake extract } \\
\text { (Madhuca indica) }\end{array}$ & - & 53.66 & 28.76 & 85.33 & 05.18 & Yes \\
\hline T10-Control- & & 75.33 & - & 90.00 & & \\
\hline SEm \pm & & 0.976 & & 1.300 & & \\
\hline CD at 5\% & & 2.900 & & 3.861 & & \\
\hline C.V. $\%$ & & 3.573 & & 3.081 & & \\
\hline
\end{tabular}

* Mean of three replications

In-Vitro Evaluation of different Oil Cake Extracts on the Inhibition of Mycelial Growth of R. Solani after 4 Days Incubation at $5 \%$ Concentration

Plate 3 A

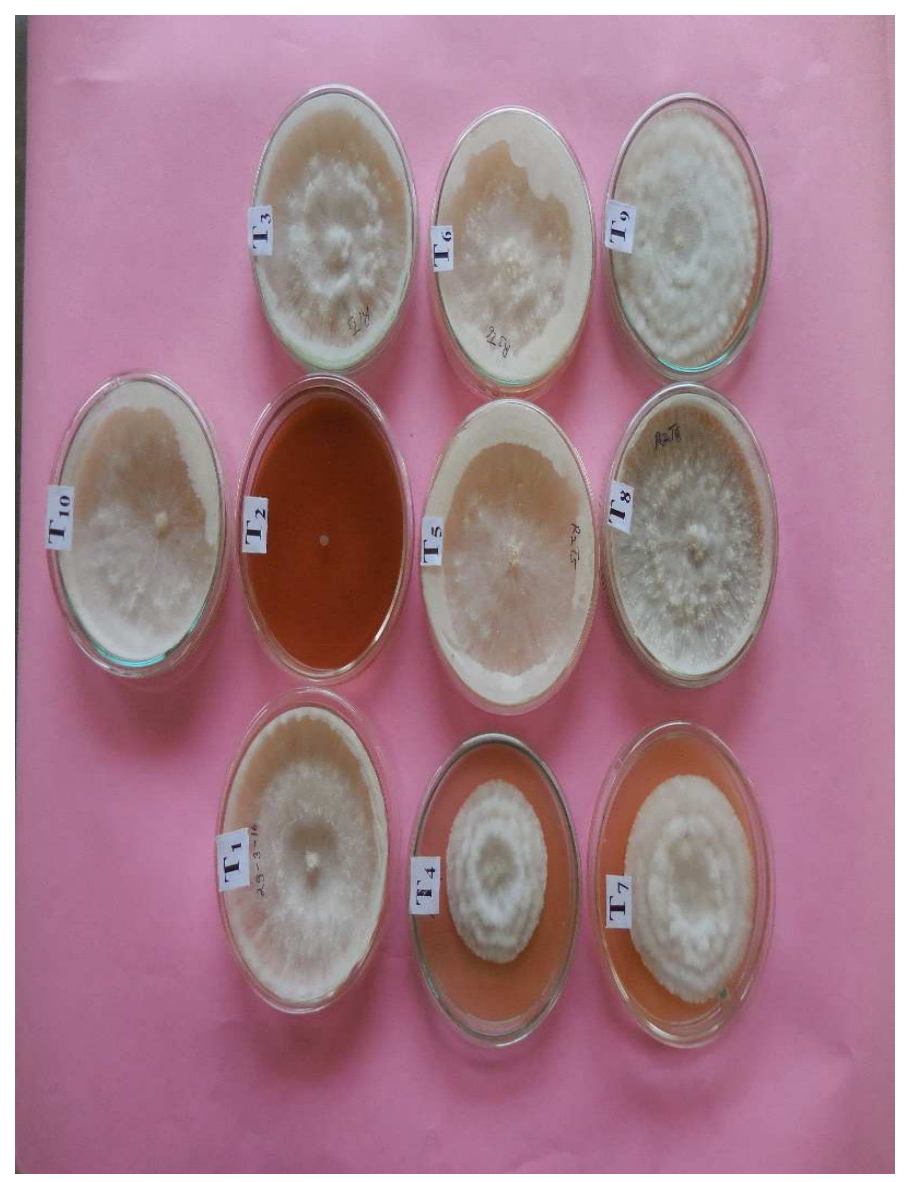

T1-Niger cake, T2-Neem cake, T3-Soybean cake, T4-Mustard cake, T5-Linseed cake, T6-Sesamum cake, T7Karanj cake, T8-Groundnut cake, T9-Mahua cake, T10-Control 

Rhizoctonia Solani Causing Frenchbean Root Rot Disease

In-Vitro Evaluation of Different oil Cake Extracts on the Mycelial Growth Inhibition of R. Solani after 7 Days Incubation at $5 \%$ Concentration

Plate 3 B

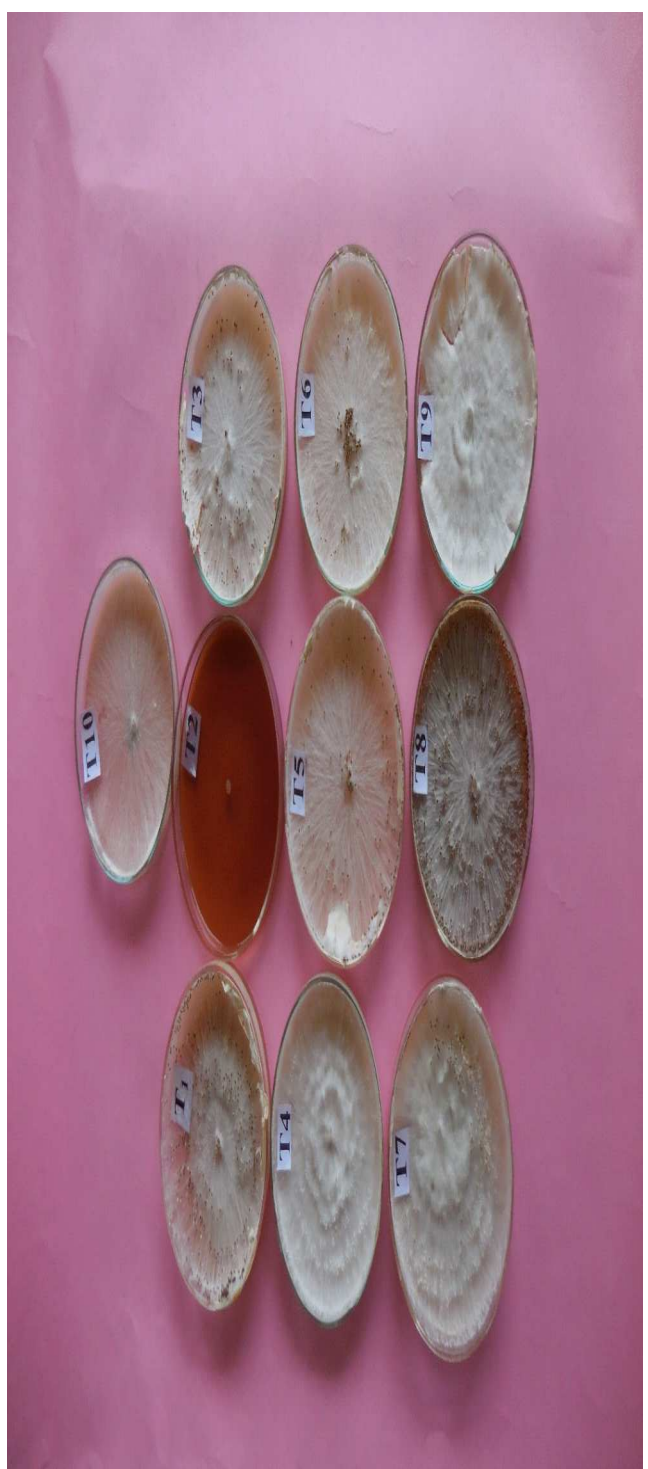

T1-Niger cake, T2-Neem cake, T3-Soybean cake, T4-Mustard cake, T5-Linseed cake, T6-Sesamum cake, T7Karanj cake, T8-Groundnut cake, T9-Mahua cake, T10-Control

Figure 3: In-Vitro Evaluation of Different Oil Cake Extracts on the Inhibition of Mycelial Growth of $R$. Solani at $5 \%$ Concentration after 4 and 7 Days Incubation 
Table 4: In Vitro Evaluation of different Oil Cakes Extracts on the Myceial Growth Inhibition of R. Solani of French Bean at 10\% Concentration After 4 and 7 Days Incubation

\begin{tabular}{|c|c|c|c|c|c|c|}
\hline \multirow[b]{2}{*}{ Treatments } & \multirow[b]{2}{*}{$\begin{array}{c}\text { Concentration } \\
(\%)\end{array}$} & \multicolumn{2}{|c|}{ After 4 Days } & \multicolumn{2}{|c|}{ After7 Days } & \multirow[b]{2}{*}{$\begin{array}{l}\text { Sclerotial } \\
\text { Production }\end{array}$} \\
\hline & & $\begin{array}{c}\text { Colony } \\
\text { Diameter } \\
(\mathrm{mm})\end{array}$ & $\begin{array}{c}\text { Growth } \\
\text { Inhibition } \\
(\%)\end{array}$ & $\begin{array}{l}\text { Colony } \\
\text { Diameter } \\
(\mathrm{mm})\end{array}$ & $\begin{array}{c}\text { Growth } \\
\text { Inhibition } \\
(\%)\end{array}$ & \\
\hline $\begin{array}{l}\text { T1-Niger cake extract } \\
\text { (Carthamus tinctrorius) }\end{array}$ & 10 & 34.66 & 40.07 & 59.00 & 31.11 & NIL \\
\hline $\begin{array}{l}\text { T2-Neem cake extract } \\
(\text { Azadirachta indica) }\end{array}$ & 10 & 10.50 & 81.84 & 30.00 & 64.97 & NIL \\
\hline $\begin{array}{l}\text { T3-Soyabean cake extract } \\
\text { (Glycine max) }\end{array}$ & 10 & 38.83 & 32.85 & 60.60 & 29.25 & NIL \\
\hline $\begin{array}{l}\text { T4-Mustard cake extract } \\
\text { (Brassica compestris) }\end{array}$ & 10 & 11.83 & 78.97 & 32.30 & 62.30 & NIL \\
\hline $\begin{array}{l}\text { T5-Linseed cake extract (Linum } \\
\text { usitatissimum) }\end{array}$ & 10 & 41.53 & 28.17 & 63.33 & 26.07 & NIL \\
\hline $\begin{array}{l}\text { T6-Sesamum cake extract } \\
\text { (Sesamum indicum) }\end{array}$ & 10 & 28.26 & 51.11 & 56.73 & 33.77 & NIL \\
\hline $\begin{array}{l}\text { T7-Karanj cake extract } \\
\text { (Pongamia pinnata) }\end{array}$ & 10 & 15.93 & 72.47 & 33.16 & 61.30 & NIL \\
\hline $\begin{array}{l}\text { T8-Groundnut cake extract } \\
\text { (Arachis hypogaea) }\end{array}$ & 10 & 28.00 & 51.62 & 53.83 & 37.16 & NIL \\
\hline $\begin{array}{l}\text { T9-Mahua cake extract (Madhuca } \\
\text { indica) }\end{array}$ & 10 & 23.53 & 59.31 & 48.06 & 43.89 & NIL \\
\hline T10-Control- & - & 57.83 & - & 85.66 & - & YES \\
\hline $\mathrm{SEm} \pm$ & & 0.717 & & 0.819 & & \\
\hline $\mathrm{CD}$ at $5 \%$ & & 2.130 & & 2.433 & & \\
\hline C.V.\% & & 4.425 & & 2.879 & & \\
\hline
\end{tabular}

* Mean of three replications

In Vitro Evaluation of Different oil Cake Extracts on the Inhibition of Mycelial Growth of $R$. Solani at $10 \%$ Concentration after 4 Days Incubation

Plate 4 A

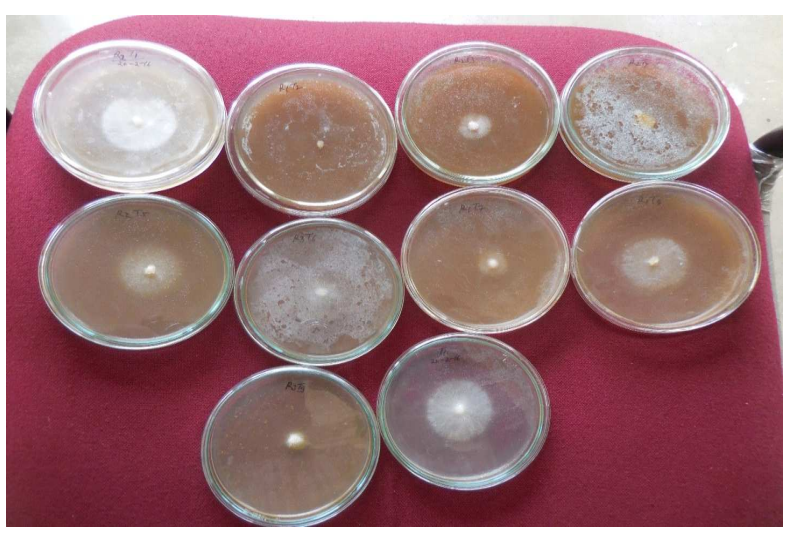

T1-Niger cake, T2-Neem cake, T3-Soybean cake, T4-Mustard cake, T5-Linseed cake, T6-Sesamum cake, T7Karanj cake, T8-Groundnut cake, T9-Mahua cake, T10-Control 
In Vitro Evaluation of Different Oil Cake Extracts on the Inhibition of Mycelial Growth of $R$. Solani at $10 \%$ Concentration After 7 Days Incubation

Plate 4 B

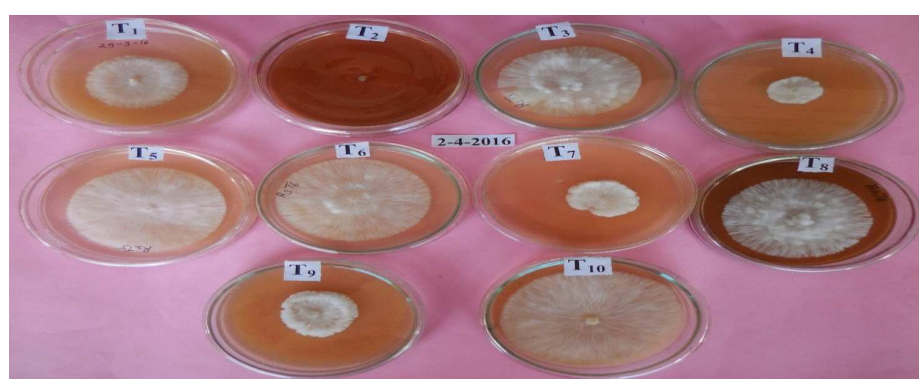

T1-Niger cake, T2-Neem cake, T3-Soybean cake, T4-Mustard cake, T5-Linseed cake, T6- Sesamum cake, T7Karanj cake, T8-Groundnut cake, T9-Mahua cake, T10-Control

Figure 4: In Vitro Evaluation of Different Oil Cake Extracts on the Inhibition of mycelial Growth of $R$. Solani at $10 \%$ Concentration after 4 and 7 Days Incubation 
